\title{
The Upper Ordovician arthropod Zonozoe drabowiensis Barrande (Libeň and Letná formations, Sandbian, Barrandian area, Czech Republic)
}

\author{
ŠTĚPÁN RAK, JAN BERGSTRÖM, OLDŘICH FATKA \& PETR BUdIL
}

\begin{abstract}
A new find of an isolated prosoma of the possible aglaspidid arthropod Zonozoe drabowiensis from the Revnice Quartzite of the Libeň Formation is described. All previously described specimens from the Letná Formation were measured and compared to this specimen, which shows the so far unknown external surface of the exoskeleton and represents the first occurrence outside the Letná Formation. - Key words: Aglaspidida, prosoma, Upper Ordovician, Prague Basin.
\end{abstract}

RAK, Š., BergStröM, J., FATKA, O. \& Budil, P. 2009. The Upper Ordovician arthropod Zonozoe drabowiensis Barrande (Libeň and Letná formations, Sandbian, Barrandian area, Czech Republic). Bulletin of Geosciences 84(1), 185-188 (2 figures). Czech Geological Survey, Prague. ISSN 1214-1119. Manuscript received January 11, 2008; accepted in revised form December 11, 2008; published online February 6, 2009; issued March 31, 2009.

Štěpán Rak, Charles University, Institute of Geology and Palaeontology, Albertov 6, 128 43, Prague 2, Czech Republic; deiphon@geologist.com • Jan Bergström, Swedish Museum of Natural History, Stockholm, Sweden; jan.bergstrom@nrm.se • Oldřich Fatka, Charles University, Institute of Geology and Palaeontology, Albertov 6, 128 43, Prague 2, Czech Republic; fatka@natur.cuni.cz • Petr Budil, Czech Geological Survey, Klárov 3, 11821 Prague 1; petr.budil@geology.cz

The Letná Formation (Upper Ordovician, Sandbian, Berounian Regional Stage) has yielded numerous species of trilobites, brachiopods, conularids, bivalves, orthoceratids and other invertebrate groups, including rare arthropods of problematic affinities: Zonozoe drabowiensis Barrande, 1872; Zonozoe sp. sensu Chlupáč (1963); Zonoscutum solum Chlupáč, 1999b; Drabovaspis complexa Barrande, 1872; Chacharejocaris? novaki Chlupáč, 1963; Triopus drabowiensis Barrande, 1872, and Caryon bohemicum Barrande, 1872. The newly found isolated prosoma of Zonozoe drabowiensis from Libeň Formation is in its general morphology comparable to all other specimens collected from the overlying Letná Formation.

All so far known fragments of possible aglaspidids originated from the "oldest fossil rich interval" of the Letná Formation (sensu Chlupáč 1965). Barrande's original material came from pits at the Děd Hill near Beroun, called by Barrande "Bande des quartzites des Mts Drabow"(see Chlupáč 1965, 1999c). These remains have been found in the association containing common Deanaspis goldfussii and Dalmanitina socialis, the typical trilobites of the Drabovia redux Community (Havlíček \& Vaněk 1990). Barrande (1852) originally described the shield of Zonozoe drabowiensis as a valve of a large ostracode.

Novák (1887) recognized the species as remains of merostomes. However, Novák's manuscript was never published. Chlupáč (1963) suggested that the above-discussed aglaspidid-like arthropods from the Letná Formation could belong to a new family or families. However, their systematic position remained doubtful.

After more recent revisions (Briggs et al. 1979, Hesselbo 1992) it seems that Zonozoe should be classified in a separate class and order (Hesselbo 1992, Hou \& Bergström 1997) outside of Chelicerata and/or as a separate subclass and order of uncertain affinities (Chlupáč 1999b). As neither opisthosoma, nor appendages of Zonozoe are known, it should be ranged only tentatively to the Aglaspidida.

Chlupáč (1963) noted that the Cambrian aglaspidids from North America differ in their morphology from the Czech questionable representatives of Ordovician age. Neostrabops martini Caster, 1952 shares some morphological similarities with aglaspidids in the shape of prosoma and in the position of supposed eye tubercles, but its systematic position remains questionable (Chlupáč 1963). Chlupáč (1965) also noted that two Siberian representatives, Chacharejocaris and probably also Girardevia occur in comparable sandstone lithofacies.

\section{Systematic part}

Phylum Arthropoda Siebold \& Stannis 1848

Order Aglaspidida Walcott, 1911

Superfamily and family uncertain

\section{Genus Zonozoe Barrande, 1872}

Type species. - Zonozoe drabowiensis Barrande, 1872.

Diagnosis. - See Chlupáč (1963), pp. 399, 400.

Species. - Zonozoe drabowiensis and Zonozoe sp., both coming from the Děd hill near Beroun, Letná Formation 

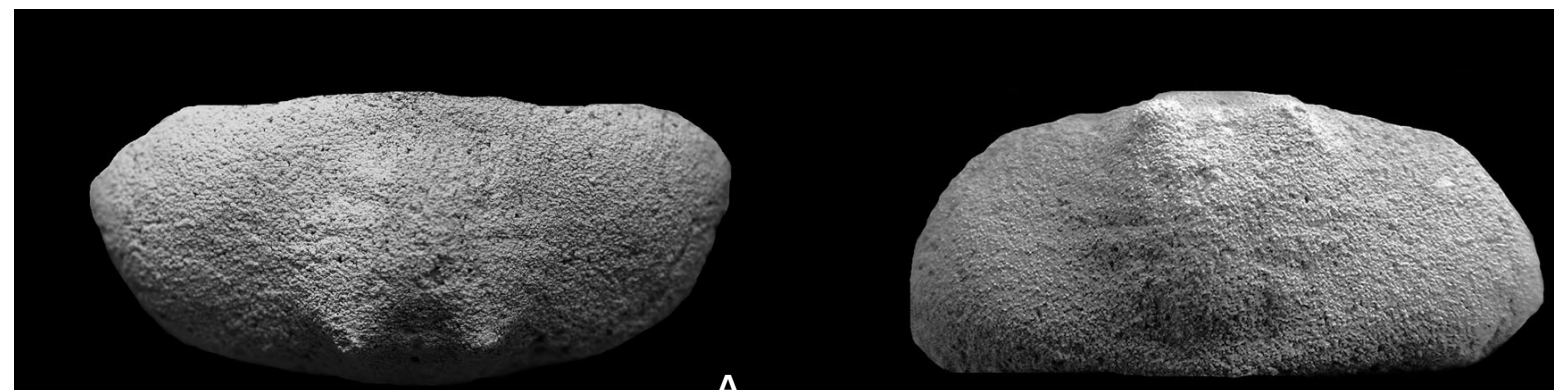

A
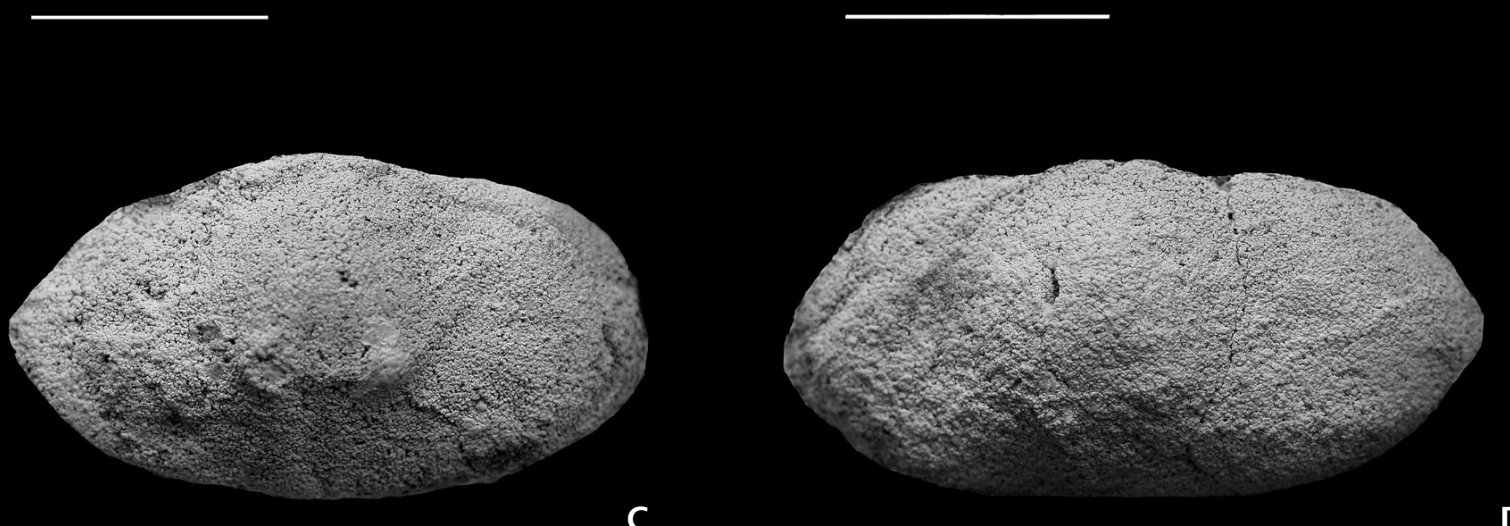

C
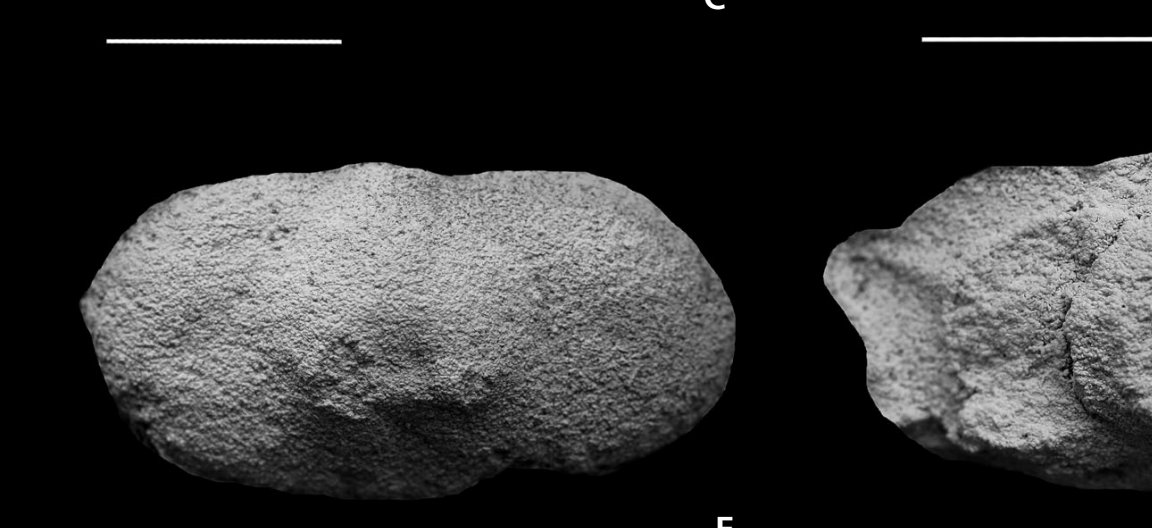

Figure 1. Zonozoe drabowiensis Barrande, 1872 from the Sandbian Stage, Upper Ordovician. Except for B, all are seen with the anterior end facing down in the figure. • A, B - Libeň Formation, Revnice Quartzite, Kařez, L 37385. A - dorsal view, B - posterodorsal view. $\bullet$ C-F - anterodorsal to dorsal views, Letná Formation, Děd near Beroun. C - L 23586, D - L 23590, E - L 32 987, F - L 32986. The scale is 10 mm.

(Sandbian, Ordovician). A new of find Z. drabowiensis come from Kařez, Libeň Formation (Sandbian, Ordovician).

\section{Zonozoe drabowiensis Barrande, 1872}

Figures 1A-F, 2

1872 Zonozoe drabowiensis Barrande; Barrande, pp. 554, 555, pl. 25, figs 33-38.

1963 Zonozoe drabowiensis Barrande. - Chlupáč, pp. 399, 400 , pl. 1, fig. 5 .
1965 Zonozoe drabowiensis Barrande. - Chlupáč, pp. 10-13, pl. 1, figs 1-8, text-fig. 1 .

1968 Zonozoe draboviensis Barrande. - Bergström, fig. $6 \mathrm{D}$.

1999a Zonozoe drabowiensis Barrande. - Chlupáč, p. 393, fig. 1a-c.

1999b Zonozoe drabowiensis Barrande. - Chlupáč, pp. 79, 80, pl. 1, figs 1-3.

Lectotype. - Internal mould of prosoma L 23586, selected herein from Barrande's types, figured by Barrande 1872, refigured by Chlupáč (1999b) on pl. 1, fig. 1. The 
former selection of a lectotype by Chlupáč 1965 (pl. 1, figs 1, 2 NM - ČD 647) cannot be regarded as valid, as the selected specimen does not belong to Barrande's original material.

Type locality and horizon. - Děd hill near Beroun, Barrandien area, Letná Formation (Sandbian, Ordovician, Czech Republic).

Material. - Seven isolated prosomata stored in the palaeontological collections of the National Museum, Prague.

Diagnosis. - See Chlupáč 1963.

Occurrence. - The upper part of the Letná Formation, the lowermost and the upper "fossil-rich intervals" sensu Chlupáč (1965), Děd hill near Beroun. The new find comes from the Revnice Quartzite Member of the Liben Formation (Sandbian, Lower Berounian), Kařez locality near Zbiroh.

Description. - The prosoma is suboval in outline, subdivided into three lobes. The lateral lobes are nearly flat, only gently convex. The rhombiform central or glabellar lobe reaches $1 / 3$ of the prosomal width, being separated from the lateral lobes by a pair of wide and shallow depressions. The glabellar region has the shape of an elongated trapezoid and possesses a pair of marked protuberances placed at the margin of the glabellar lobe about 1/3 from the anterior margin. A shallow but distinct median depression in the glabella is deepest between the eye tubercles. The convexity of the glabellar region is best visible in anterior view (hence the predominant orientation in Figs 1 and 2). Behind the eye tubercles, three pairs of lateral furrows are impressed, dissecting the glabellar region transversally. The first two furrow pairs are directed anteroventrally. The posterior one of them is longer and almost transverse. The most posterior furrow is short and inclined to the transverse line. The posterior margin of the glabellar region is narrow and flat. Laterally the prosoma is distinctly vaulted, both in transverse and longitudinal course. Its central part is flattened, the genal region broadly vaulted, ending in a blunt or rounded corner. The doublure is wide and slightly concave.

\section{Discussion}

The new specimen of Zonozoe drabowiensis has been found in context with fragments of abundant Dalmanitina cilinensis, orthid brachiopods (Drabovia, Petrocrania) and conularids (Anaconularia, Metaconularia). Based on studies of Havlíček (1992, 1998), sandstones of the Letná and Libeň formations contain the Drabovia Assemblage that
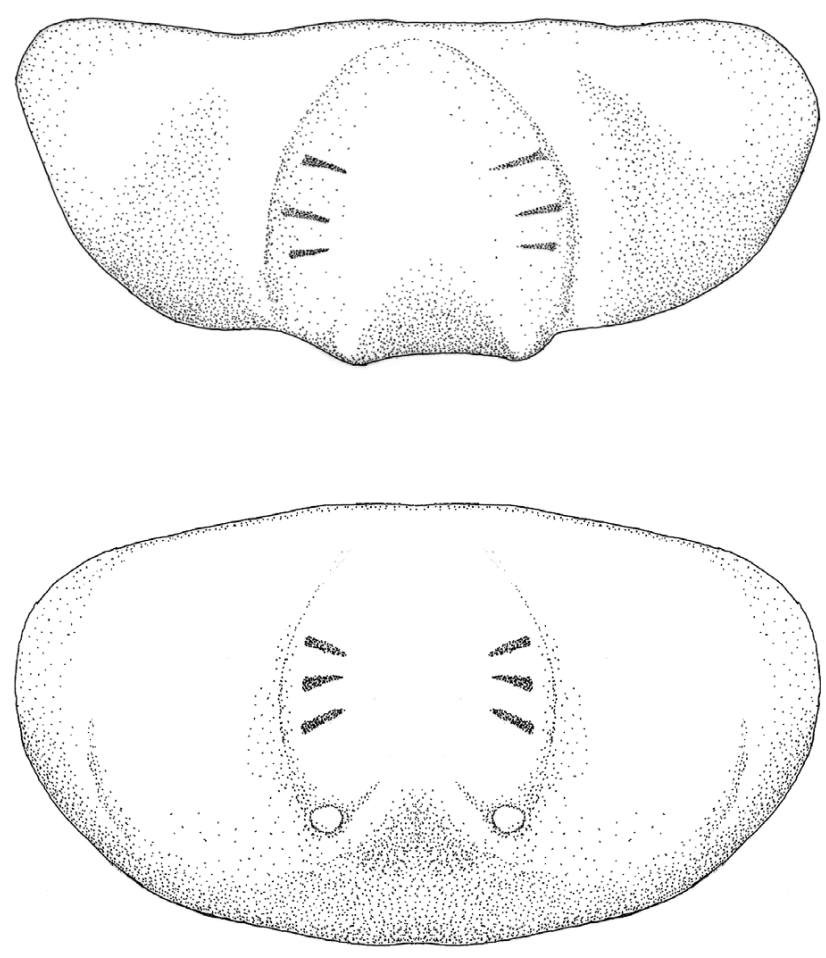

Figure 2. Drawing of the new prosoma of Zonozoe drabowiensis (L 37385) to show the glabellar region with eye tubercles and glabellar furrows. Posterodorsal (above) and anterodorsal (below) views, in both cases with the anterior end facing downwards.

inhabited a high-energy shallow subtidal environment characterized by fragmented skeletons and shells. Also Šnajdr (1956) discussed the strong similarity in the faunal content and facies developments of these two units. Most taxa established in the Revnice Quartzites range into the quartzites of the Letná Formation. Especially, the composition of trilobite faunas is strongly similar, with common Dalmanitina, Stenopareia, Actinopeltis, Selenopeltis, and Primaspis. The new find of the isolated prosoma of Zonozoe drabowiensis is another indication of comparable life habits of the possible aglaspidids in both stratigraphic levels.

\section{Conclusions}

The recently found prosoma of Zonozoe drabowiensis is an external mould and shows glabellar furrows, which are not preserved in any of the six earlier known specimens which are preserved as internal moulds.

Glabellar furrows were reported also by Chlupáč (1999b) in the holotype of Zonoscutum solum. However, in this species, these furrows are positioned below the eye tubercles. Both species share similar preservation in quartzites. Therefore, the presence and/or absence of the glabellar furrows in these aglaspidid-like arthropods could be affected by the taphonomic bias. 


\section{Acknowledgments}

We are grateful to J. Král and Š. Manda for valuable comments on an early version of the manuscript. The contribution was supported by the project MSM 0021620855, 205/06/0395. We thank also to R. Šarič for technical help with drawing the Figure 2.

\section{References}

BARRANDE, J. 1852. Systême silurien du centre de la Bohême, Vol. I., Trilobites. Prague \& Paris.

BARRANDE, J. 1872. Systême silurien du centre de la Bohême: I. Partie, Supplement au Vol. I. Trilobites, Crustacés divers et Poissons. Prague \& Paris.

Briggs, D.E.G., Bruton, D.L. \& WhitTington, H.B. 1979. Appendages of the arthropod Aglaspis spinifer (Upper Cambrian, Wisconsin) and their significance. Palaeontology 22, 167-180.

CASTER, K.E. \& MACKE, W.B. 1952. A new aglaspid (Neostrabops martini) from the Upper Ordovician of Ohio. Journal of Paleontology 26, 753-755.

CHLUPÁČ, I. 1963. Report on the merostomes from the Ordovician of Central Bohemia. Věstník Ústředního ústavu geologického 38, 399-402.

CHLUPÁC̆, I. 1965. Xiphosuran merostomes from the Bohemian Ordovician. Sborník geologických věd, Paleontologie 5, 7-38.

CHLUPÁČ, I. 1999a. Unusual arthropods from the Bohemian Or- dovician - a review. Acta Universitatis Carolinae, Geologica 43(1-2), 393-396.

CHLUPÁČ, I. 1999b. Some problematical arthropods from the Upper Ordovician Letná Formation of Bohemia. Journal of the Czech Geological Society 44(1-2), 79-87.

CHLUPÁČ, I. 1999c. Barrande's stratigraphic concepts, paleontological localities and tradition - comparison with the present stage. Journal of the Czech Geological Society 44(1-2), $3-30$.

HAVLíČEK, V. 1982. Ordovician of Bohemia: Development of the Prague Basin and its benthic communities. Sborník geologických věd, Geologie 37, 103-136.

HAVlíČEK, V. in CHLUPÁČ, I., HAVLíČEK, V., KŘíž, J., KUKAL, Z. \& S̆TORCH, P. 1998. Paleozoic of the Barrandian (Cambrian to Devonian). 183 pp. Czech Geological Survey Prague.

HAVLÍČEK, V. \& VANĚK, J. 1990. Ordovician invertebrate communities in black-shale lithofacies (Prague basin, Czechoslovakia). Věstník Ústředního ústavu geologického 65, 223-236.

HESSELBO, S.P. 1992. Aglaspidida (Arthropoda) from the Upper Cambrian of Wisconsin. Journal of Paleontology 66(6), 885-924.

Hou, X, \& BergströM, J. 1997. Arthropods of the Lower Cambrian Chengiiang fauna. Fossils and Strata 45, 116.

NovÁK, O. 1887. Merostomata. Manuscript deposited in the National Museum in Prague.

ŠNAJDR, M. 1956. Trilobiti drabovských a letenských vrstev českého ordoviku. Sborník Ústředního ústavu geologického $22,1-57$. 